\title{
Alternative Sanitation and Strategic Directives for the Well Water Security in Cotonou (Benin) and Lomé (Togo)
}

\author{
Henri S. Totin Vodounon ${ }^{1 *}$, Emilia M. Azalou-Tingbé², Koko Z. Houedakor ${ }^{3}$, Ernest Amoussou', \\ Mafobatchie Nantob ${ }^{4}$, Gloria A. Adoho ${ }^{2}$, Léocadie Odoulami ${ }^{5}$
}

\author{
${ }^{1}$ Department of Geography and Territory Planning, University of Parakou, Parakou, Benin \\ ${ }^{2}$ Department of Sociology, University of Abomey-Calavi, Cotonou, Benin \\ ${ }^{3}$ Centre for Integrated Coastal and Environmental Management, University of Lomé, Lomé, Togo \\ ${ }^{4}$ Department of Sociology, University of Lomé, Lomé, Togo \\ ${ }^{5}$ Department of Geography and Territory Planning, University of Abomey-Calavi, Cotonou, Benin \\ Email: *totinsourouhv@gmail.com, emiliamawugnon@gmail.com, koko.houedakor@gmail.com, ajernest@yahoo.fr, \\ nantob_bobo@yahoo.fr, affiadoho@gmail.com, leocadieo@yahoo.com
}

\begin{abstract}
How to cite this paper: Totin Vodounon, H.S., Azalou-Tingbé, E.M., Houedakor, K.Z., Amoussou, E., Nantob, M., Adoho, G.A. and Odoulami, L. (2021) Alternative Sanitation and Strategic Directives for the Well Water Security in Cotonou (Benin) and Lomé (Togo). Journal of Water Resource and Protection, 13, 675-698. https://doi.org/10.4236/jwarp.2021.139036
\end{abstract}

Received: July 17, 2021

Accepted: September 5, 2021

Published: September 8, 2021

Copyright ( 2021 by author(s) and Scientific Research Publishing Inc. This work is licensed under the Creative Commons Attribution International License (CC BY 4.0).

http://creativecommons.org/licenses/by/4.0/ (c) (i) Open Access

\begin{abstract}
In the coastal cities of West Africa, land use change, rapid population growth, bad sanitation systems and poor environmental governance degrade the quality of groundwater. This study aimed to assess alternative, acceptable, affordable sanitation disposal and practices for groundwater quality rehabilitation in the cities of Cotonou and Lomé. The study was based on the participatory transdisciplinary approach, field surveys, feedback from interactions with stakeholders, experiences of the practitioners and institutional consultations. This multi-stakeholder approach helped to appreciate ecological aspects of sanitation disposal and its implications on water quality improvement. SWOT model was used to analyze the relevance of assessed ecological system. Well water quality is deteriorated by traditional waste management disposal. Ecological sanitation systems are septic tanks on polyethylene, above-ground latrines and phytoremediation technique in the swamp areas. Collected wastes are used for composting and biogas production. Based on the optimist scenario at 2030 horizon, kind success factors of groundwater security are participation of citizens, existence of sanitation market, valorization of the waste by category, low-cost disposal adaptable to the individual, household and neighborhood's scales. The strategic directions rely on funding and public policies for WASH, ecological sanitation disposal, cultural environment and good sanitation practices for emergence of new sanitation system to secure and sustain well water quality. But the social acceptability of ecological disposal is limited by the society's multicultural heritage. These findings could help in de-
\end{abstract}


cision-making concerning urban groundwater quality protection in the African coastal cities.

\section{Keywords}

Socio-Ecology, Sanitation, Well Water Quality, SWOT, Scenario, Social Acceptability

\section{Introduction}

Groundwater is a vital source of drinking water in African towns and cities; however, this resource has often been compromised by the combined use of aquifers as a repository for human waste [1] [2] contamination sources such as wastewater basin, latrines and gutters. The current environmental governance linked urban linear metabolism leads to high level of pollution, notably in the informal settlements. Indeed, the threats to urban groundwater result from inadequate sanitation and hygiene infrastructure and the proximity to lakes and lagoons, etc. Related to urbanization, Zaporozec et al. [3] cited domestic and municipal solid waste disposal, disposal of domestic wastewater, disposal of collected wastewater and effluents, salvage and junkyards and other urban sources. Almost $85 \%$ to $90 \%$ of global wastewater is discharged without treatment [4] (Corcoran et al., 2010).

Thus, in the cities of Cotonou and Lomé, the available groundwater has a poor quality (therefore inaccessible) because of poor sanitation and inappropriate hygienic practices. In these towns, the basic disposal of wastes and excreta management are gutters, swamps, sumps, streets, courtyards of house, pit latrine and septic tank [5] [6] [7] [8]. The bad status of these sanitation infrastructures affects groundwater quality, compromising safe water supply to citizens. Groundwater, mostly from shallow aquifers is polluted with faecal coliforms on these two cities [9]-[15]. In this context, the past and current sanitation systems can't be that which could help to achieve the sustainability of domestic water use in the poor African cities. The emergence of new water management concepts over time involves water security [16]. A sustainable and environmentally healthy water resource management is important to ensure, in the future, drinking water quality and quantity [17]. So an integrated representation of socio-ecological systems can help to support local communities to move towards sustainability [18]. Indeed, social planning has come to be synonymous with technical forecasting [19]. This paper is based on the theory that safe groundwater will not be accessible in coastal cities due to poor sanitation and inappropriate hygiene practices. However, socio-ecological mechanisms of solid, liquid and excreta waste management can reduce groundwater pollution. To this end, we explore a highly interconnected relationship between human societies and ecosystems defined by Royce and Behailu [20] to positively impact the hydro system by safe sanitation. 
Universal clean sanitation has been promoted as one of the pillars of the United Nations' Sustainable Development Goals (SDGs) for 2030 [21]. Also, with regard to the Intergovernmental Hydrological Programme of the United Nations Educational, Scientific and Cultural Organization (UNESCO-IHP) post-2015 goal "ensure water security for sustainable development" and the challenges of urban sustainability, it is necessary to develop socio-ecological systems to protect groundwater. According to Berkes \& Folke [22], social-ecological systems are linked systems of people and nature, emphasising that humans must be seen as a part of, not apart from, nature.

A new sanitation system will help restore and protect groundwater quality through changes in the behaviour of the urban people. The issue is to propose a socially accepted eco-hydrological approach for aquifer rehabilitation and protection, and improvement of well water quality in the coastal cities. This challenge leads to the exploration of the concepts like ecological sanitation and environmental sanitation, used by the World Health Organization (WHO) [23] and Langergraber and Muellegger [24]. So, based on a conceptual scheme for integrating social and ecological systems in the city [25] (Grimm et al., 2000) the ecological sanitation challenges will be co-designed taking into account changes in urban ecology and in the perceptions and attitudes of the citizens. We explore the argument developed by Bijker et al. [26] which certified that the stabilisation of technology results from involving the social groups in designing and using technology and their final decision of a solved problem. This can drive ecological patterns and processes governing groundwater quality to guarantee the availability of safe domestic water for the two cities over a long period of time. But the socio-ecological systems are associated with numerous constraints such as increased urbanization, pressure on land availability, environmental variability, etc. [27] that will be analysed through the Strengths-Weaknesses-Opportunities -Threats (SWOT) approach.

The objective of this paper is to highlight ecological sanitation disposal, socially adaptable for groundwater rehabilitation and its quality improvement in the coastal cities as Cotonou and Lomé.

\section{Materials and Methods}

\subsection{Study Area}

Cotonou and Lomé cities are located in West Africa (Figure 1). These border countries are established on the coastal sandy and marshy plain between the Atlantic Ocean and lagoons or lakes. The sites are 4 to $6 \mathrm{~km}$ long [28] and 2 to 3 $\mathrm{km}$ long [29] respectively and have relatively flat and irregular topography with 0.4 to $6.5 \mathrm{~m}$ and $5 \mathrm{~m}$. Soils with $80 \%$ being coarse sand and porosity exceeding $40 \%$ in Cotonou [28] facilitate infiltration and fast transfer of pollutants from sewage, wastewater basin, landfills and latrines towards water systems mostly shallow aquifers (Quaternary). The climate of these two cities is subequatorial with two dry seasons and two rainy seasons. These cities have respectively an average 
rainfall of $1300 \mathrm{~mm} / \mathrm{yr}$ and $800 \mathrm{~mm} / \mathrm{yr}$ with annual temperatures of $27.7^{\circ} \mathrm{C}$ and $27.9^{\circ} \mathrm{C}$. Interaction between natural and human factors enhances ecological risk of aquifer contamination from unsafe sanitation disposal especially on the time of yearly floods.

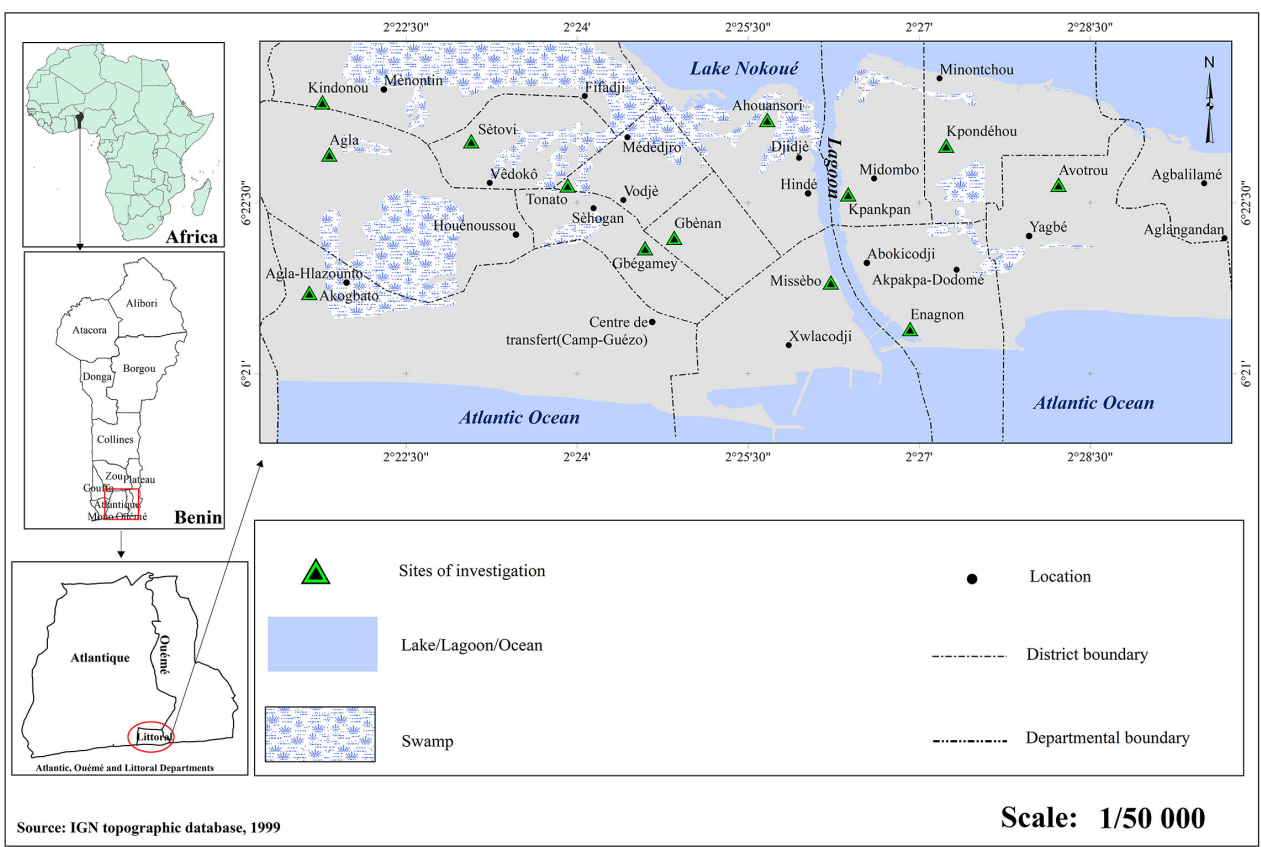

(a)

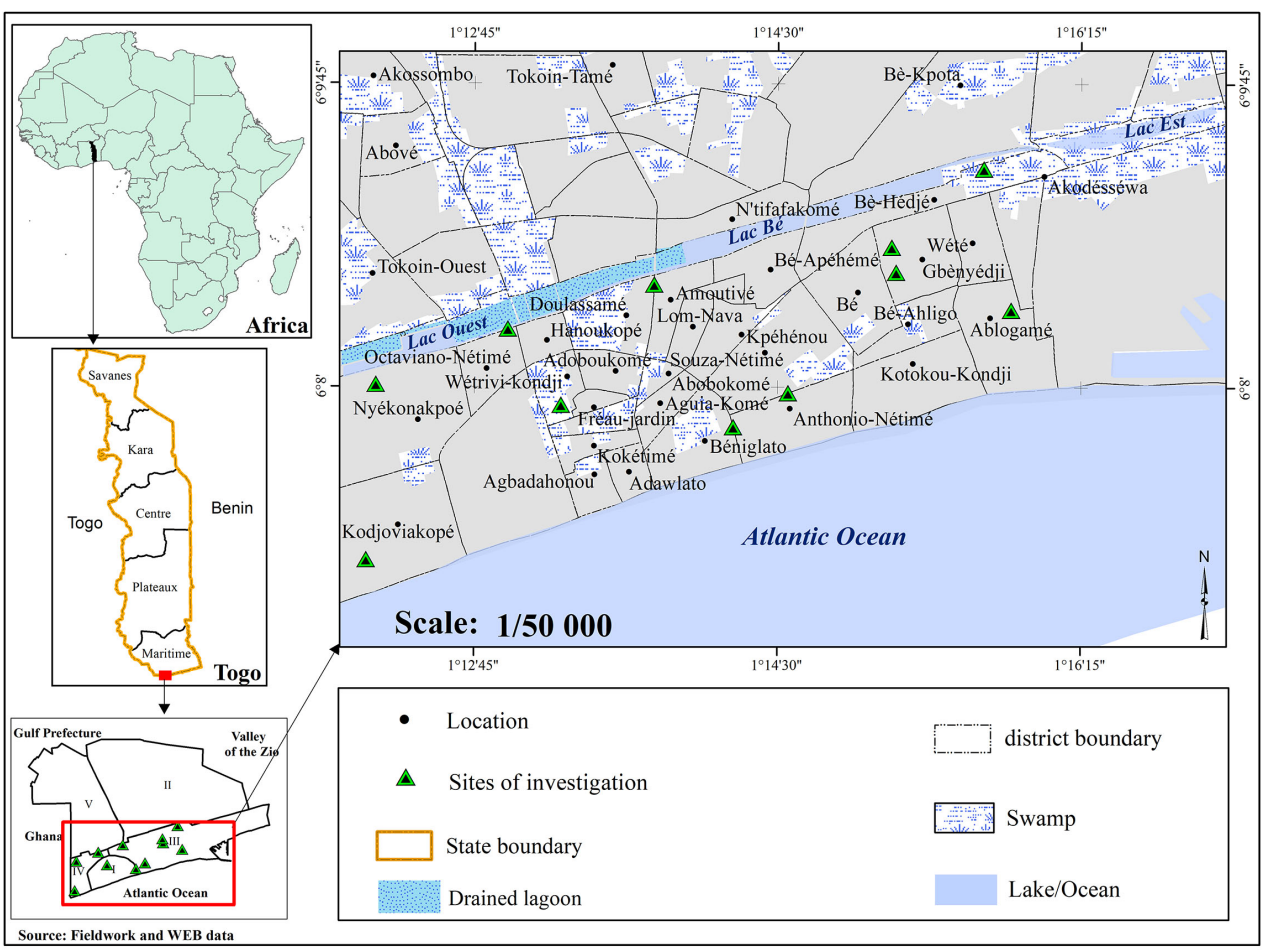

(b)

Figure 1. Geographical location of the cities of Cotonou (a) and Lomé (b) and socio-anthropological survey sites. 
The social system is dominated by the cities' poorly planned, informal settlements and inadequate basic socio-community infrastructures such as Water, Sanitation and Hygiene (WASH). Rapid population growth in Cotonou with a high density $\left(14,591\right.$ people $\left./ \mathrm{km}^{2}\right)$ and in Lomé $\left(11,985\right.$ people $\left./ \mathrm{km}^{2}\right)$ has as a consequence increased production of solid and liquid wastes and excreta (0.6 $\mathrm{kg} / \mathrm{hab} /$ day and $0.596 \mathrm{~kg} / \mathrm{hab} /$ day). While the solid waste collection is operational, the wastewater and excreta collection system is unregulated and uncontrolled. Thus, negative effects of improper waste management include the alteration of the environment and water systems such as groundwater [9] [12] [13] [14].

Due to urban sprawl and spatial saturation residents of Cotonou $\left(79 \mathrm{~km}^{2}\right)$ and Lomé $\left(90 \mathrm{~km}^{2}\right)$ live in a complex environment marked by improper waste management and leachate and faecal contamination of groundwater. In this context, human health is affected by the bad groundwater quality due to faecal contamination [12] [15] [30]. Focusing on WASH related to SDGs 3, 6 and 11, the two cities have been chosen as the study area.

\subsection{Data}

This study is carried out in the selected case study area, based on the following criteria: an unhealthy neighbourhood, a higher people density, existence of a garbage dump, wastewater drainage disposal, type of excreta disposal. These criteria are retained on the basis of expert judgment which governs their choice and directs how they can help to assess the human pressure impacts on the environment health and well water quality.

Questionnaire, direct field observation and institutional consultancy helped to collect data on well water, sanitation, hygiene and disposals.

\subsection{Transdisciplinary Research Approach}

To improve groundwater management, the value of drawing on theory and methods from social research is increasingly recognising [31]. The study was carried out using the transdisciplinary approach [32]-[40] which involves all stakeholders in the various steps of the research to generate new, comprehensive knowledge and an overarching synthesis on best sanitation practices. Applied transdisciplinary approach in this study leads community-based stakeholders in evaluating and identifying the sources of domestic well water contamination. This enables also to evaluate on-going experiences of best sanitation practices and co-production ecological disposal to secure groundwater quality.

Taken transdisciplinary action [41] involved the inclusion of stakeholders (in the two cities) in framing of the problem statement (sanitation and quality of well water in the two cities), field data collection on existing sanitation and hygiene disposals, analysis of the results and adoption of socio-ecological systems to sustain groundwater quality. In practical terms, our research consortium included academics geographers, sociologists, hydrogeologists, civil engineers, architects, specialists in public health, sanitation and hygiene, and urbanists as well as non-academic groups such as urban residents, business interest groups, civil 
society, government agencies working on Water Sanitation and Hygiene (WASH) and municipality offices, urban community government. At the first step of this approach diverse groups jointly identify the problems of current sanitation and hygiene linked groundwater quality degradation.

Stakeholders engagement in direct research facilitated the transdisciplinary co-production of knowledge (breaking the boundaries between science and society) on the ecological sanitation practices to protect and sustain groundwater quality. Research took the form of local field visits (in situ analysis of sanitation and hygiene disposal and interactions with domestic wells, interviews on 115 households per city, and engaged researcher-stakeholder group discussions for a new knowledge creation, addressing concerned sanitation problem solving by ecological disposal.

Finally, the results of scientific studies were integrated into societal and scientific practices to promote acceptable, affordable sanitation practices and disposal to improve the quality of groundwater and, ultimately, to provide safe domestic well water to the urban communities. Knüppe and Pahl-Wostl [42] supported also this research approach explaining that in the groundwater context, stakeholders to involve are scientists, policy makers, farmers, Indigenous people and environmental interests, and there are clear benefits from not excluding these key actors.

\subsection{SWOT Analysis of Sanitation Disposals versus Groundwater Quality}

A SWOT analysis [43] [44] [45] [46] helped to assess factors that can influence the ecological disposal for groundwater quality protection. This analytical model can provide a good basis for strategy formulation [47] which is used for audits and strategic planning [48] and so serves as an important support tool for decision-making [43].

SWOT analysis enables understanding of strengths, weaknesses, opportunities and threats involved in any activity [49] or can be used to interpret a plan under complex conditions [50] as waste management in the coastal urban area. Thus, a SWOT Matrix is established to identify these strengths and weakness (internal factors) and these opportunities and threats (external factors) on the views of environmental, political, social, economic or cultural vectors of behaviours change. Use of the SWOT analysis can help to show the efficiency (or inefficiency) of operation [51] that correspond in this study to the adoption of ecological sanitation disposal to secure and sustain urban groundwater quality. It also helps to define the strategic orientations for sustainable water, sanitation, hygiene and health systems.

\section{Results and Discussion}

\subsection{Citizen' Logics of the Relationship between Society and Environment}

The study areas are a multicultural environment, bringing together in the same 
territory several groups of people from various areas, and with different perceptions and practices. Sanitation and hygiene in these towns are perceived as the fact of purifying their immediate living environment, making it clean. Paradoxically, streets, abandoned houses, swamps, gutters, soils, lake, lagoon, etc. serve as discharge sites of generated waste.

According to Ogu [52], in several developing countries, such as Nigeria, the inadequacy of urban land development and planning has led to concerns regarding the environmental sustainability of the urban centers. A cohabitation of urban people with solid, liquid or excreta wastes (Figure 2) is observed as revealed in Dakar by APHRC [53]. In the middle cities of Burkina Faso, Bouraima [54] revealed the human-waste relationship in its multidimensionality. These behaviors linked to the traditional waste management system contribute to the degradation of groundwater quality because of the fracture of the equilibrium between the social and ecological systems. Also, there is a lack of public environmental awareness generating acceptance of alternative solutions [55]. Figure 3 shows the perception the urban people with regards to practices that can contaminate groundwater.

Wastewater disposal near wells (33\% in Cotonou; 32\% in Lomé) and inappropriate household waste management (36\% in Cotonou; $21 \%$ in Lomé) are the main sources of well water contamination in these cities. Associated factors of pollution are poor installation of sanitation facilities (11\% in Cotonou; $15 \%$ in Lomé) and proximity of the well to sanitation disposal (7\% in Cotonou and $14 \%$ in Lomé). In this context, according to UN-Water [56], environmental conditions arising from inadequate or non-existing wastewater management pose significant threats to human health, well-being and economic activity.

To reduce the damage caused by the bad sanitation and inadequate hygienic practices on groundwater, socio-ecological solutions are necessary for the sustainability of safe water supply on the two cities.

Adoption of the new ecological sanitation and hygiene systems allows the protection against contamination sources and progressive improvement of well water quality by reducing of pollutant transfer in the cities.

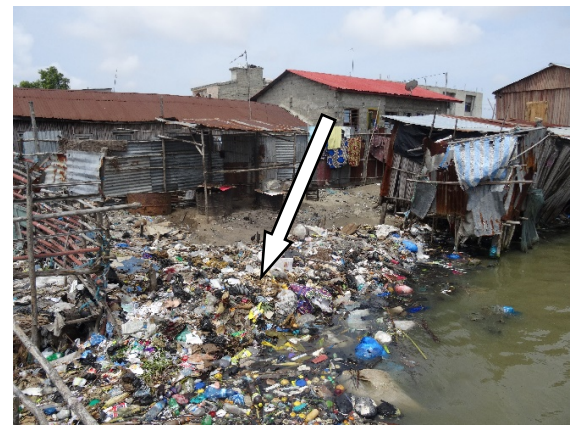

(a)

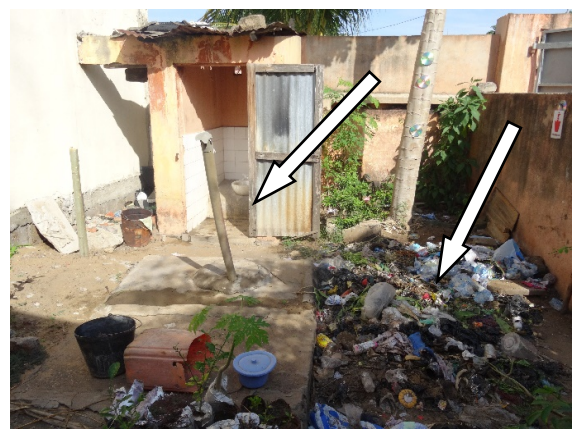

(b)

Figure 2. Households cohabitation with wastes on the cities of Cotonou (a) and Lomé (b) (Photos: H.S. Totin Vodounon, June 2019). 


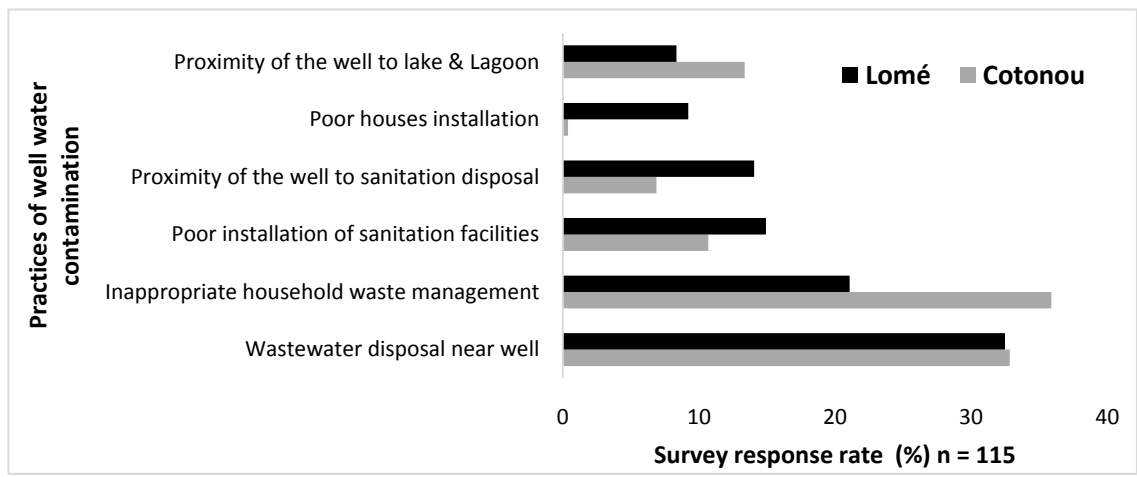

Figure 3. People perceptions of practices contributing in groundwater contamination.

\subsection{Experimental Socio-Ecological Systems of Sanitation}

The population is aware that it will be necessary to improve the household waste management. Waste valorisation [6] [57] [58], according to the field survey results, includes compost (fertilizers for vegetables; $44 \%$ in Cotonou and $45 \%$ in Lomé), fuels (biogas; $21 \%$ in Cotonou and $16 \%$ in Lomé), materials (transformation of plastic wastes on blocks for road construction; $24 \%$ in Cotonou and $16 \%$ in Lomé). To this end, ecological garbage cans are sued in sorting waste, to avoid odour pollution, animal vandalism and pollutants infiltration toward the shallow aquifers.

With regard to the current linear urban metabolism in Cotonou [5] [7] [15], a future circular bioeconomy [59] presents an opportunity for sustainability of the cities. Recycling and reuse of liquid waste in agriculture, wetland governance and energy can contribute to this kind of economy if positive wastewater management behaviours are adopted in the two cities. Andersson et al. [60] link recycling water resources to less freshwater abstraction from natural systems to meet human demand, contributing to environmental sustainability.

Concrete septic tanks require the use of heavy concrete or brick structures which over time present certain drawbacks such as lack of waterproofing. In this case with the rapid development of modern technologies, ecological disposal of wastewater and excreta management can be through the use of Polyethylene septic tanks, above-ground watertight pit latrine in swampy environment as presented in Figure 4 and phyto-purification by Eichhornia crassipes (water hyacinth) at household or neighbourhood level or and natural lagoon. These ecological systems have been inspired from existing experiences capitalized by the Songhaï Centre in Benin and NGO ENPRO (Safe Natural Ecosystem) in Togo concerning integrated ecological sanitation and biogas production by waste methanization (Figure 5). Methane is of significant importance due to the large amount formed during the decomposition of organic wastes [61].

The phytoremediation of wastewater [62] [63] using Eichhornia crassipes or other invasive plants is adapted to the swamp neighbourhoods. Eichhornia crassipes accumulates heavy metals, dyes, radionuclides, and other organic and inorganic contaminants from water [64]. The depolluting plants will be recovered to produce biofuels [65] or for manufacturing briquette [66], within the sus- 
tainable development plan of the two cities. On an individual or household scale, the phytoremediation disposal installation is supplied by water from toilets and kitchen.
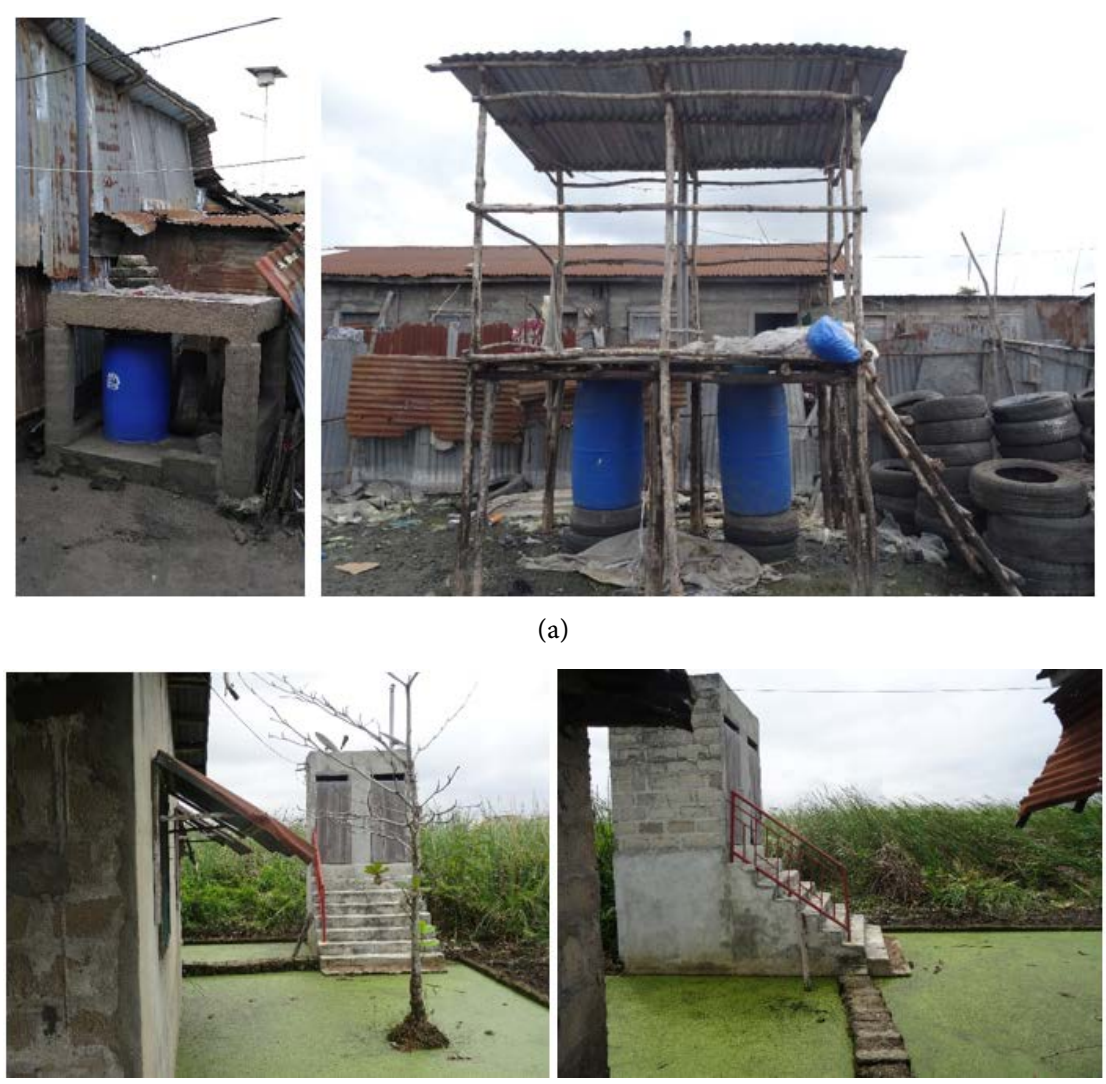

(b)

Figure 4. Experimental septic tanks in plastic polyethylene at Ahouansori Towéta (a) and ecological above-ground watertight pit latrine in swampy environment of Agla in Cotonou (b) (Photos: H.S. Totin Vodounon, August 2019).

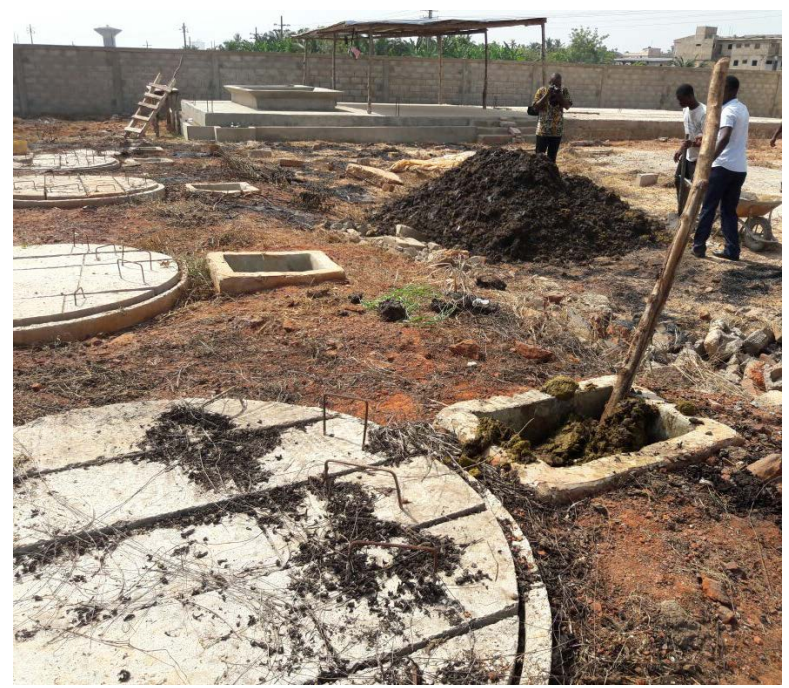

Figure 5. Methanization and biogas production disposal in Lomé (Photos: E. Chokpon, July 2020). 
As noted by Andersson et al. [50], vast economic (as well as social and environmental) benefits for societies could be provided by sustainable sanitation and wastewater management. With these sustainable ecological disposals adapted to the flooding areas, the waste (solid waste, wastewater and excreta) cannot contaminate aquifers systems. Sauer et al. [67] confirm that a high priority for many cities is the protection of groundwater by ecological farming. So, it provides sustainable groundwater protection in African coastal cities.

\subsection{Internalization of Socio-Ecological Systems by Citizens}

The success of the ecological sanitation is its acceptability by urban people. According to Esrey et al. [68], the strangest aspect of ecological sanitation options is the fact that it requires from households, certain manipulations of its products. Indeed, concerns have been expressed by urban people about the cultural potential [69] or acceptability and health aspects of the ecological sanitation systems.

The cultural acceptability of ecological sanitation depends on "positive associations between sanitation and fertilizer production enabling quite significant changes in attitudes towards human excreta" [70]. Understanding attitudes and behaviour of the target population in order to design feasible eco-sanitation systems has also been the interest of Nawab et al. [71]. So, the participation of urban stakeholders can lead to activate the socio-ecological transition of cities in order to preserve water system and sustain safe water supply. This can help to avoid the failure of an ecological sanitation program when put in place without the participation of concerned users. Donadei [72] reasoned that a population actively involved is a key element to activate a change; it has to understand nature, and to build real alternatives to the current model of territory occupation based on the ecological paradigm.

With the transdisciplinary approach (participatory and inclusive), evoked socio-ecological systems are selected to be implemented in order to improve well water quality in the study areas. However, the social and cultural conditionshabits, beliefs, values and practices that influence the design of the "social" components of a sanitation system, its acceptability or "adjustment" within the community are not static; new practices are constantly developing in many societies [68]. Sauer et al. [67] demonstrate that depending to regarded cities, the actors involved with the water system assessed the socio-ecological transition (SET) differently. So, in Cotonou and Lomé, cosmopolite cities, a social transformation to secure groundwater need habits monitoring for possible and permanent adjustment. This transformative change may involve as highlighted by Berkes [73], institutional change, technological innovation, behavioural shifts, and cultural change.

\subsection{SWOT Analysis of the Socio-Ecological Sanitation Practices}

\subsubsection{Solid Waste Management System}

The system adopted with the population for the protection of the quality of the 
groundwater is the selective collection system based on the market economy. Its implementation will lead citizens to no longer use the streets, abandoned houses, swamps, gutters, soils, lake, lagoon as waste discharge sites.

The SWOT analysis of this system is presented in Table 1.

Using the SWOT model for the urban waste management analysis, Eheliyagoda [74] found as key points of strengths location of the solid waste management centre, regular waste collection, establishment of waste purchasing and recycling centres, strong awareness and training programmes on promoting municipal solid waste management, waste taxation and availability of finance. Mor et al. [49] evoked practice of door-to-door collection of waste with fixed monthly charges payment by residents. But this strategy failed in Cotonou and Lomé because of the proximity of houses to swamps where urban people directly dump garbage. Otherwise, political support is crucial for successful participation of civil society initiatives [67] on the urban solid waste management.

\subsubsection{Wastewater Management System}

Ecological management of wastewater involves pre-treatment before discharged in the natural ecosystems. Among the wastewater treatment techniques, phytopurification is one of those adapted to the context of sustainable development, because it not only protects the environment, but also promotes the development of flora. Phytoremediation by water hyacinth is therefore an ecological system to eliminate pollutants of wastewater before its discharge in the environment. This practise can progressively help in reducing groundwater contamination by liquid waste. The development for phyto-purification could be carried out in swamping neighbourhoods. SWOT analysis of this system is in Table 2.

Table 1. SWOT Analysis of selective waste collection system.

\begin{tabular}{|c|c|}
\hline Strengths & Opportunity \\
\hline \multicolumn{2}{|l|}{ Participation of urban population } \\
\hline Increase in household income & Existence of experimental Centre (Centre \\
\hline Sorting of waste & $\begin{array}{l}\text { Songhai, Programme VALDERA in Benin; } \\
\text { NGOs STADD and ENPRO in Togo) }\end{array}$ \\
\hline $\begin{array}{l}\text { Existence of waste buying and recycling centers } \\
\text { Valorization of the waste by category }\end{array}$ & $\begin{array}{l}\text { Existence of economy and sanitation value chain } \\
\text { interest (Business Interest Groups) }\end{array}$ \\
\hline $\begin{array}{l}\text { Protection against groundwater pollution by } \\
\text { landfill }\end{array}$ & $\begin{array}{l}\text { Waste management project on the National } \\
\text { Development Plan }\end{array}$ \\
\hline Production of natural fertilizers & Promotion of organic products \\
\hline \multicolumn{2}{|l|}{ Environmental Protection } \\
\hline Weaknesses & Threat \\
\hline $\begin{array}{l}\text { Insufficient sorting and recovery centers for } \\
\text { household's waste }\end{array}$ & Incivism of urban people \\
\hline $\begin{array}{l}\text { Unavailability of human, technical and financial } \\
\text { resources }\end{array}$ & $\begin{array}{l}\text { No adhesion of the urban communities } \\
\text { Lack of coordination of waste collection company }\end{array}$ \\
\hline
\end{tabular}


Table 2. SWOT Analysis of wastewater management system.

\begin{tabular}{|c|c|}
\hline Strengths & Opportunity \\
\hline \multicolumn{2}{|l|}{ Development of aquatic flora } \\
\hline Low investment cost & Existence of swamps \\
\hline $\begin{array}{l}\text { Landscape integration } \\
\text { Easy to be realized at the household and } \\
\text { neighbourhoods scale }\end{array}$ & $\begin{array}{l}\text { Existence of lakes and lagoons connected to the } \\
\text { swamps }\end{array}$ \\
\hline Weaknesses & Threat \\
\hline \multicolumn{2}{|l|}{ Requires more space } \\
\hline Odour pollution & Lack of wastewater collection service \\
\hline $\begin{array}{l}\text { Created hydrosystem can increase proliferation } \\
\text { of mosquitoes }\end{array}$ & $\begin{array}{l}\text { Acceptability by riparian population } \\
\text { Accumulation of waste }\end{array}$ \\
\hline $\begin{array}{l}\text { Necessity of specific pollutants remediation } \\
\text { plants }\end{array}$ & Filling of the phytoremediation basin by waste \\
\hline
\end{tabular}

Starkl et al. [75] identified strengths as low energy requirements, benefits of side products, high acceptance for reuse of treated wastewater while weaknesses are high land requirements, odour and mosquitoes from the wastewater basin near human settlements. The weaknesses are the challenge to face in the study areas. Within the framework of relationships between urban community-based, technology and nature, Van De Meene [76] and Bell [77] revealed the challenges of wastewater treatment technologies and the shift from traditional to more sustainable approaches. The basic mechanisms can be recycling and reuse of wastewater that has to be made with dual water supply system for new layouts [78] adaptable to the complex coastal areas of Cotonou and Lomé.

\subsubsection{Excreta Waste Management System}

Strande et al. [79] highlight that the faecal sludge contains faeces and urine, toilet paper, anal rinsing water, and even greywater or flushing water. Reuse of nutrients from human faeces and urine is the basis for excreta ecological sanitation. Excreta and urine can be used as components of compost and biogas production. With regard to the permanent humid environment of the two cities, composting dry toilets, watertight pit latrines, above ground latrine and reinforced concrete septic tanks, and polyethylene septic tank are those adapted. The SWOT analysis of this excreta management disposal is presented in Table 3.

According to Andersson and Minoia [80] ecological toilets can consist of cheap and easy appliances; one important dimension is that their adoption must depend upon potential users' choices, coherently with their cultural sensitivity and possible consideration as livelihoods resources.

\subsection{Socio-Environmental Challenges versus Groundwater Quality: Scenarios and Strategic Directives}

Diagnosis of the environmental system revealed three sub-systems established as an institutional framework, a living area, and a socio-cultural framework. 
Table 3. SWOT Analysis of excreta management system.

\begin{tabular}{|c|c|}
\hline Strengths & Opportunity \\
\hline $\begin{array}{l}\text { Adaptable to the individual and collective } \\
\text { house }\end{array}$ & $\begin{array}{l}\text { Possibility to use technological advances to manage } \\
\text { excreta }\end{array}$ \\
\hline $\begin{array}{l}\text { Protection of the environment against faecal } \\
\text { pollutants }\end{array}$ & $\begin{array}{l}\text { Promotion of the use of natural fertilizers and biogas } \\
\text { Promotion of organic products }\end{array}$ \\
\hline Weaknesses & Threat \\
\hline Requires frequent draining & Social acceptability \\
\hline $\begin{array}{l}\text { Risks of odour rising } \\
\text { Perception of the population }\end{array}$ & Health risks \\
\hline
\end{tabular}

Responses to the various questions linked to the sub-system highlight the anticipation ability of arising situations. Key aspects by sub-system are: institutional frame (public policies and mobilisation of financial resources; sustainable living environment (waste management and ecological system) and socio-cultural framework (social acceptability and social practices/behaviours change). This combination helps to identify the challenges and issues of the socio-ecological sanitation system.

The main challenges to be overcome are the poor management of waste by the existing sanitation and hygiene system and the adoption of an ecological system, in order to reduce the degradation of groundwater quality. The concern of social acceptability refers to the inextricable link between the sociological and technical considerations. Mariwah and Drangert [81] recommend open discussions in the community to success the ecological sanitation implementation. This challenge must be taken up within an appropriate institutional framework in order to ensure the system a contributing role to development and within the cultural framework in order to bring society, in this case the urban communities, to change sanitation and hygiene behaviours and habits with the aim of the sustainable restoration of aquifers. To overcome these challenges and ensure the protection of groundwater quality, global scenarios have been formulated for each of the sub-systems in Table 4.

\subsubsection{Social Change on the Global Optimistic Scenario}

The urban population, on the process of social change, understanding the consequences of its actions on the environment and on its health, begins progressively leaving bad behaviour such as: discharge the wastewater on streets, abandoned houses, swamps, gutters, soils, lake, lagoon, etc. Curtis et al. [31] evoked changes in human behaviour as condition of environmental improvements.

To sustain the effective membership of urban communities, waste produced is recovered free of charge from households by the management structures. So, the behaviour of citizens changes completely and they work in synergy with the Municipality and the Basic Hygiene and Sanitation Offices. Indeed, the classic sanitation system which contaminate groundwater and degrade of the quality of 
Table 4. Summary of global scenarios for the sub-systems of the WASH system.

\begin{tabular}{|c|c|c|c|}
\hline Sub-system & Global optimistic scenario & $\begin{array}{l}\text { Global intermediate } \\
\text { scenario }\end{array}$ & $\begin{array}{l}\text { Global pessimistic } \\
\text { scenario }\end{array}$ \\
\hline $\begin{array}{l}\text { Institutional } \\
\text { framework }\end{array}$ & $\begin{array}{l}\text { Performance of public } \\
\text { policies and strong } \\
\text { mobilization of } \\
\text { resources }\end{array}$ & $\begin{array}{l}\text { Performance of public } \\
\text { policies and strong } \\
\text { mobilization of resources }\end{array}$ & $\begin{array}{l}\text { Ineffective public policies } \\
\text { and poor resource } \\
\text { mobilization }\end{array}$ \\
\hline Living area & $\begin{array}{l}\text { Improving waste } \\
\text { management and } \\
\text { adopting an ecological } \\
\text { sanitation system }\end{array}$ & $\begin{array}{l}\text { Improving waste } \\
\text { management and } \\
\text { adopting an ecological } \\
\text { sanitation system }\end{array}$ & $\begin{array}{l}\text { Poor waste management } \\
\text { and rejection of the } \\
\text { ecological system by } \\
\text { citizens }\end{array}$ \\
\hline $\begin{array}{l}\text { Socio-cultural } \\
\text { framework }\end{array}$ & $\begin{array}{l}\text { Good social acceptability } \\
\text { and good social behaviour } \\
\text { change practices }\end{array}$ & $\begin{array}{l}\text { Poor social acceptability } \\
\text { and bad social practices }\end{array}$ & $\begin{array}{l}\text { Poor social acceptability } \\
\text { and bad social practices }\end{array}$ \\
\hline
\end{tabular}

well water is controlled and stopped. From the short to long terms (horizon 2030), groundwater is protected from any contamination source and its quality is progressively and permanently improved. According to Dietz et al. [82], effective groundwater governance is easier in the framework where the user population, the uses, and economic and social conditions are relatively stable or change only moderately, and where communities that use the resource frequently interact.

With regard to this, urban population can have access to well water, use safe water for all it needs, including drinking, and avoid water-borne diseases. The limit concerning this scenario focusing on one of the theory of Inglehart and Wayne [83] is that values can change, but they will reflect a society's cultural heritage. So, on the view of Minato et al. [84] development of positive social norms is one strategy that can be used to influence adoption of new practices.

\subsubsection{Social Change on the Global Intermediate Scenario}

The population of the two cities, despite efforts of the various actors, has mixed behaviours or is resistant to change. According to Moser et al. [85], social resistance to certain adaptation strategies is influenced among others by attitudes, cultural norms, place attachment and historical investments. In the study areas, people are coping with the domination of cultural influence and consider that "water cannot be dirty". Private waste management companies frequently visit the neighbourhoods and households to recover waste produced, but the streets, unbuilt houses, swamps, gutters, soils, lake and lagoon are still used as discharge site.

Urban communities therefore do not change their habits and continue with the classic system of sanitation and hygiene, resulting from the vicious linear metabolism which contributes to groundwater pollution in the cities. By 2030, groundwater quality will be completely degraded and can no longer serve the needs of the urban population. People continue to spend money for safe drinking water and take care of the health risks associated with living in a polluted environment and consuming contaminated well water. This scenario refers in accordance with Llmas [86] to the need of the participation of the social groups 
and stakeholders, which should begin in the early stages and should be, as much as possible, bottom-up in the water development projects.

\subsubsection{Social Change on the Global Pessimistic Scenario}

Urban population continue with their old habits which consist of waste discharge on swamps near households, drainage of wastewater and excreta in the gutters, lake and lagoons. In correspondence to this scenario, we agree with Inglehart and Wayne [83] who highlight that the influence of traditional value systems is unlikely to disappear, however, as belief systems exhibit remarkable durability and resilience. This could be related to the cultural nature of cities as they are not planned, but spontaneous [87] mostly in a large part of Africa. So, in the study areas, face to the government resignation and the providing of bad sanitation services, urban residents continue also with their inappropriate practices (throwing waste water in the street, the courtyard of house or the unbuilt area, emptying the sumps in the street and the gutters ...).

The linear urban metabolic system and groundwater (well water) quality deterioration persists. By the horizon 2030, groundwater quality (shallow and deep aquifers) is completely degraded and it can no longer be used for any need. People spend a lot of money for safe drinking water needs and health problems due to a polluted environment and the consumption of water with poor quality. To cope this challenge, Garduño et al. [88] proposed that stakeholder participation is essential because it facilitates the coordination of decisions relating to groundwater, land-use and waste management and generally reduces cross-sector contradictions.

Depending on the consistency, plausibility and realism, the optimistic scenario is that securing groundwater is the desired one by 2030 .

\subsubsection{Strategies for Groundwater Security}

The role of strategies is to help the effective realization of the desired future by building a framework of general strategic directives and an operational strategic framework for development. Therefore, they constitute the translation of the results and views of the population into development policy. They help, based on the objectives, to identify necessary resources to achieve them.

In this study, the SWOT analysis tool served to design strategies that reflect the realities of water, sanitation and hygiene system. Thus each of the strategies was the subject of a confrontation between the internal and external factors of the system. The vision of concerned actors, the strengths and constraints of the internal and external environment as well as the opportunities and threats on these cities' groundwater served as a basis to assess the implementation framework of the system. The formulated strategic guidance has been summarized in Table 5 .

The strategic diagnosis of water sanitation and hygiene as well as the analysis of the role of stakeholders led to the identification of the challenges these cities are facing. 
Table 5. Strategic orientations for water sanitation, hygiene and health system.

\begin{tabular}{|c|c|c|c|c|}
\hline Sub-system & Major issues & Strategic objectives & Strategic issues & Strategic directions \\
\hline \multirow[b]{2}{*}{$\begin{array}{l}\text { Institutional } \\
\text { framework }\end{array}$} & $\begin{array}{l}\text { Weakness of } \\
\text { public policies }\end{array}$ & $\begin{array}{l}\text { Increase public } \\
\text { policies }\end{array}$ & $\begin{array}{l}\text { How to bring out } \\
\text { public policies? }\end{array}$ & $\begin{array}{l}\text { Reinforcement of public } \\
\text { policies for WASH }\end{array}$ \\
\hline & $\begin{array}{l}\text { Low financial } \\
\text { resource } \\
\text { mobilization }\end{array}$ & $\begin{array}{l}\text { Increase funding } \\
\text { of WASH and } \\
\text { health sectors }\end{array}$ & $\begin{array}{l}\text { How to improve } \\
\text { the level of } \\
\text { financial resources } \\
\text { devoted to the } \\
\text { sector? }\end{array}$ & $\begin{array}{l}\text { Increase funding of } \\
\text { WASH and public health }\end{array}$ \\
\hline \multirow{2}{*}{ Living area } & $\begin{array}{l}\text { Poor management } \\
\text { of solid, liquid and } \\
\text { excreta waste }\end{array}$ & $\begin{array}{l}\text { Improve solid, } \\
\text { liquid and excreta } \\
\text { waste management }\end{array}$ & $\begin{array}{l}\text { How to establish } \\
\text { ta new ecological }\end{array}$ & \multirow{2}{*}{$\begin{array}{l}\text { Adoption of an ecological } \\
\text { sanitation disposal for } \\
\text { the restoration and } \\
\text { preservation of } \\
\text { groundwater quality }\end{array}$} \\
\hline & $\begin{array}{l}\text { Adoption of } \\
\text { ecological } \\
\text { sanitation system }\end{array}$ & $\begin{array}{l}\text { Develop and adopt } \\
\text { the ecological } \\
\text { system }\end{array}$ & $\begin{array}{l}\text { system for waste } \\
\text { management? }\end{array}$ & \\
\hline \multirow[t]{2}{*}{$\begin{array}{l}\text { Socio-cultural } \\
\text { framework }\end{array}$} & $\begin{array}{l}\text { Low social } \\
\text { acceptability } \\
\text { proposed } \\
\text { disposal }\end{array}$ & $\begin{array}{l}\text { Facilitate social } \\
\text { acceptability of } \\
\text { ecological } \\
\text { sanitation }\end{array}$ & $\begin{array}{l}\text { How to get citizen } \\
\text { to accept the new } \\
\text { sanitation and } \\
\text { hygiene system? }\end{array}$ & $\begin{array}{l}\text { Promotion of cultural } \\
\text { environment for } \\
\text { emergence of new } \\
\text { ecological sanitation } \\
\text { system }\end{array}$ \\
\hline & $\begin{array}{l}\text { Bad social } \\
\text { practices }\end{array}$ & $\begin{array}{l}\text { Changing the } \\
\text { social practices }\end{array}$ & $\begin{array}{l}\text { How to get citizen } \\
\text { to change their } \\
\text { behaviour? }\end{array}$ & $\begin{array}{l}\text { Promotion of good } \\
\text { sanitation and hygiene } \\
\text { practices }\end{array}$ \\
\hline
\end{tabular}

In the institutional framework, the public policies can include, based on the analysis of Jabeen et al. [89] environment, sanitation, drinking water policies. According to Ramakrishnaiah [78], the chances for success of the policies to be adopted depend on public support for and understanding and compatibility of the policies with overall economic efficiency, environmental quality and equity objectives. Related to funding of WASH, Ezenwaji et al. [90] estimated that microfinance institutions should be meant to charge low interest rates on loans allocated to households for water supply and sanitation and that the urban water policy includes this innovative funding practice. In Cotonou and Lomé, this financial strategy leading to the self-supply of water can help as shown by Ezenwaji et al. [91] in Onitsha (Nigeria) to improve the condition of domestic wells and its water quality and to expand the capacity of water supply yielding the better access, reliability and cost effectiveness. The social dimension of city sustainability and development addressing informalities in urban growth, social inclusion [92] is a basis of the promotion of cultural environment for emergence of new ecological sanitation system controlled by good practices. On the other hand, ecological sustainability, economic feasibility, localized cultural and social acceptability are a basis of ecological sanitation [80].

\section{Conclusions}

On the basis of this study, citizens of Cotonou and Lomé recognize the vul- 
nerability level of urban groundwater to contamination mainly from inappropriate household waste management, wastewater disposal near wells and poor installation of sanitation facilities. Therefore, the main challenges of the water-sanitation-hygiene-health system in these two cities are improvement and adoption of an ecological system, in order to reduce the degradation of well water quality. To limit shallow aquifers contamination, waste valorisation takes a form of composting, recycling and reuse of liquid waste, biogas production, use of the plastic wastes to produce blocks for road construction. Other ecological sanitation options are the phytoremediation of wastewater and progressive replacement of pit latrines by polyethylene septic tanks. But, the success of the sustainability of these ecological sanitation systems depends on its sociocultural acceptability by urban residents.

To this end, the most strengths of the SWOT analysis are citizen's participation in urban management planning, affordable new ecological disposal and adaptability to the individual, household and neighbourhood's scales. So on the basis of the elaborated global optimistic, intermediate and pessimistic scenarios, formulated strategic directions related to the WASH sub-systems (institutional context, living area, socio-cultural framework) are the increase of funding and public policies for WASH and public health, adoption of ecological sanitation disposal, taking into account the cultural environment for the emergence of new ecological sanitation system, engagement for good sanitation and hygiene practices (behaviours change).

The desired probabilistic scenario is that of protection of domestic well water quality and reduction of its degradation by unsafe sanitation. This socio-ecological approach can lead to a vision of sustainable systems of water, sanitation and hygiene and public health. Indeed, in the long term, this effective ecological system is adopted by the urban communities for well water protection in the African coastal areas. In the context of achieving the Sustainable Development Goals (SDGs), establishment of ecological sanitation systems socially accepted is a considerable step forward for groundwater security in the West African coastal cities.

\section{Acknowledgements}

This work is based on research supported wholly by the LIRA 2030 Africa Programme, which is implemented by the International Science Council (ISC) in partnership with the Network of African Science Academies (NASAC), with support from the Swedish International Development Cooperation Agency (Sida).

The present research has been approved by the Ethical Committee of Biomedical Research, University of Parakou, Benin (Ref. No. 0299/CLERB-UP/P/SP/SA of 14/05/2020). Informed consent was obtained from each participant before their inclusion on the transdisciplinary research team.

\section{Conflicts of Interest}

The authors declare no conflicts of interest regarding the publication of this paper. 


\section{References}

[1] Taylor, R.G., Tindimugaya, C., Barker, J.A., Macdonald, D. and Kulabako, R. (2004) Convergent Radial Tracing of Viral and Solute Transport in Gneiss Saprolite. Groundwater, 48, 284-294. https://doi.org/10.1111/j.1745-6584.2008.00547.x

[2] Cronin, A.A., Pedley, S., Hoadly, A.W., Kouonto Komou, F., Haldin, L., Gibson, J. and Breslin, N. (2007) Urbanisation Effects on Groundwater Chemical Quality: Findings Focusing on the Nitrate Problem from 2 African Cities Reliant on On-Site Sanitation. Journal of Water and Health, 5, 441-454. https://doi.org/10.2166/wh.2007.040

[3] Zaporozec, A., Conrad, E.J., Hirata, R., Johansson, P.O., Nonner, J.C., Romijn, E. and Weaver, C.M.J. (2004) Groundwater Contamination Inventory: A Methodological Guide. International Hydrological Programme within Project 3.1 (IHP-V), Series on Groundwater No. 2, United Nations Educational, Scientific and Cultural Organization, Paris.

[4] Corcoran, E., Nellemann, C., Baker, E., Bos, R., Osborn, D. and Savelli, H. (2010) Sick Water? The Central Role of Wastewater Management in Sustainable Development. United Nations Environment Programme/United Nations Human Settlements Programme/GRID-Arendal (UNEP/UNHabitat), Nairobi.

[5] Adédémi, F.C. (2020) Métabolisme urbain, systèmes d'assainissement et d'hygiène et risques sanitaires dans la ville de Cotonou (République du Bénin). MSc Thesis, Université d'Abomey-Calavi, Cotonou.

[6] Adoho, A.G. (2020) Systèmes socio-écologiques d'assainissement et d'hygiène pour la qualité des eaux souterraines à Cotonou à l'horizon 2030. MSc Thesis. Université d'Abomey-Calavi, Cotonou.

[7] Koffi, Y.T. (2020) Métabolisme urbain, système d'assainissement et d'hygiène et risques sanitaires dans la basse ville de Lomé (République du Togo). MSc Thesis. Université de Lomé, Lomé.

[8] Chokpon, E. (2020) Systèmes socio-écologiques d'assainissement et d'hygiène pour la durabilité de la qualité des eaux souterraines dans la basse ville de Lomé (Togo). MSc Thesis, Université de Lomé.

[9] Boukari, M. (1998) Fonctionnement du système aquifère exploité pour l'approvisionnement en eau de la ville de Cotonou sur le littoral béninois. Impact du développement urbain sur la qualité des ressources. Ph.D. Thesis, Université Cheick Anta Diop, Dakar.

[10] Odoulami, L. (2009) Problématique de l'eau potable et la santé humaine dans la ville de Cotonou (République du Bénin). Ph.D. Thesis, Université d'Abomey-Calavi, Cotonou.

[11] Tampo, L., Ayah, M., Kodom, T., Tchakala, I., Boguido, P., Bawa, L.M. and Djanéyé-Bouindjou, G. (2014) Impact de la demande en chlore et de la chloration sur la désinfection des eaux de puits des quartiers de Lomé: Cas des quartiers de Démakpoé et d'Agbalépédogan (Togo). Journal of Applied Biosciences, 75, 6272 6281. https://doi.org/10.4314/jab.v75i1.12

[12] Soncy, K.B., Anani, K., Eklou-Lawson, M., Adjrah, Y., Karou, D.S., Ameyapoh, Y. and de Souza C. (2015) Évaluation de la qualité bactériologique des eaux de puits et de forage à Lomé, Togo (Assessment of the Bacteriological Quality of Well and Borehole Water in Lomé, Togo). Journal of Applied Biosciences, 91, 8464-8469. https://doi.org/10.4314/jab.v91i1.6

[13] Sokegbe, Y.O., Djeri, K.E., Kangnidossou, M., Mensah, T.R., Soncy, K. and Ameyapoh, Y. (2017) Les risques sanitaires liés aux sources d'eau de boisson dans le district no. 
2 de Lomé-commune: Cas du quartier d'Adakpamé. International Journal of Biological and Chemical Sciences, 11, 2341-2351. https://doi.org/10.4314/ijbcs.v11i5.31

[14] Diallo, A., Sebastien, S., Gnandi, K., Tittikpina, N., Bakoma, B. and Salou, M. (2020) Evaluation of the Physico-Chemical Quality of Drinking Water in Two Districts of Lomé (Togo). Research Journal of Environmental Toxicology, 14, 1-7. https://doi.org/10.3923/rjet.2020.1.7

[15] Totin Vodounon, S.H. (2020) Métabolisme urbain et saisonnalité de la qualité des eaux de puits dans la ville côtière de Cotonou au Bénin. Revue des Sciences Environnementales Université, Lomé, 17, 25-43.

[16] Hoekstra, Y.A., Buurman, J. and van Ginkel, C.H.K. (2018) Urban Water Security: A Review. Environmental Research Letters, 13, Article ID: 053002. https://doi.org/10.1088/1748-9326/aaba52

[17] Marlow, D.R., Moglia, M., Cook, S. and Beale, J.D. (2013) Towards Sustainable Urban Water Management: A Critical Reassessment. Water Research, 47, 7150-7161. https://doi.org/10.1016/j.watres.2013.07.046

[18] Singh, S.J., Haberl, H., Gaube, V., Grünbühel, C.M., Lisivieveci, P., Lutz, J., Matthews, R., Mirtl, M., Vadineanu, A. and Wildenberg M. (2010) Conceptualising Long-Term Socio-Ecological Research (LTSER): Integrating the Social Dimension. In: Müller, F., Baessler, C., Schubert, H. and Klotz, S., Eds., Long-Term Ecological Research: Between Theory and Application, Springer, Dordrecht, 377-398.

http://www.scopus.com/inward/record.url?eid=2-s2.0-84892351805\&partnerID=M N8TOARS

https://doi.org/10.1007/978-90-481-8782-9_26

[19] Murphy, J.W. (1981) Applied Sociology, Social Engineering, and Human Rationality. The Journal of Sociology \& Social Welfare, 8, Article No. 3. https://scholarworks.wmich.edu/jssw/vol8/iss1/3

[20] Royce, F. and Behailu, B. (2014) A Metric and Frameworks for Resilience Analysis of Engineered and Infrastructure Systems. Reliability Engineering \& System Safety, 121, 90-103. https://doi.org/10.1016/j.ress.2013.07.004

[21] Daudey, L. (2018) The Cost of Urban Sanitation Solutions: A Literature Review. Journal of Water, Sanitation and Hygiene for Development, 8, 176-195. https://doi.org/10.2166/washdev.2017.058

[22] Berkes, F. and Folke, C. (Eds.) (1998) Linking Social and Ecological Systems: Management Practices and Social Mechanisms for Building Resilience. Cambridge University Press, New York.

[23] World Health Organization (WHO) (2005) Sanitation and Hygiene Promotion: Programming Guidance. WHO Library Cataloguing-in-Publication Data, World Health Organization, Geneva, 27.

[24] Langergrabera, G. and Muelleggera, E. (2005) Ecological Sanitation-A Way to Solve Global Sanitation Problems? Environment International, 31, 433-444. https://doi.org/10.1016/j.envint.2004.08.006

[25] Grimm, B.N., Grove, M.J., Pickett, A.T.S. and Redman, L.C. (2000) Integrated Approaches to Long-Term Studies of Urban Ecological Systems. BioScience, 50, 571-584. https://doi.org/10.1641/0006-3568(2000)050[0571:IATLTO]2.0.CO;2

[26] Bijker, W.E., Hughes, T.P. and Pinch, T. (2012) The Social Construction of Technical Systems: New Directions in the Sociology and History of Technology. The MIT Press, Cambridge, London.

[27] Bousquet, F., Anderies, M., Antona, M., Bassett, T., Benjaminsen, T., et al. (2015) Socio-Ecological Theories and Empirical Research. Comparing Social-Ecological 
Schools of Thoughts in Action. CIRAD-GREEN, Philadelphia, hal-01130178.

[28] Maliki, A.R. (1993) Etude hydrologique du littoral béninois dans la région de Cotonou (Afrique de l'Ouest). Ph.D. Thesis, Université Cheick Anta Diop, Dakar.

[29] Programme des Nations Unies pour l'Environnement (PNUE) (2007) Rapport national sur l'environnement marin et côtier (National Report on the Marine and Coastal Environment). Technical Report, Ministry of Environment, Lomé.

[30] Hounsounou, E.O., Tchibozo, M.A.D., Kelome, N.C., Vissin, E.W., Mensah, G.A. and Agbossou, E. (2016) Pollution des eaux à usages domestiques dans les milieux urbains défavorisés des pays en développement: Synthèse bibliographique (Pollution of Water for Domestic Use in Disadvantaged Urban Areas of Developing Countries: Bibliographical Summary). International Journal of Biological and Chemical Sciences, 10, 2392-2412. https://doi.org/10.4314/ijbcs.v10i5.35

[31] Curtis, A., Mitchell, M., Mendham, E. (2016) Social Science Contributions to Groundwater Governance. In: Jakeman, A.J., Barreteau, O., Hunt, R.J., Rinaudo, JD. and Ross, A., Eds., Integrated Groundwater Management, Springer, Cham, 477-492. https://doi.org/10.1007/978-3-319-23576-9_19

[32] Klein, J.T. (2007) Interdisciplinary Approaches in Social Science Research. In: Outwaite, W. and Turner, S.P., Eds., The Sage Handbook of Social Science Methodology, Sage Publications, Los Angeles, 32-49.

[33] Petts, J., Owens, S. and Bulkeley, H. (2008) Crossing Boundaries: Interdisciplinarity in the Context of Urban Environments. Geoforum, 39, 593-601.

https://doi.org/10.1016/j.geoforum.2006.02.008

[34] Pohl, C. (2010) From Transdisciplinarity to Transdisciplinary Research. Transdiciplinary: Journal of Engineering \& Science, 1, 65-73.

https://doi.org/10.22545/2010/0006

[35] Mobjörk, M. (2010) Consulting versus Participatory Transdisciplinarity: A Refined Classification of Transdisciplinary Research. Futures, 42, 866-873. https://doi.org/10.1016/j.futures.2010.03.003

[36] Lang, J.D., Wiek, A., Bergmann, M., Stauffacher, M., Martens, P., Moll, P., Swilling, M. and Thomas, J.C. (2012) Transdisciplinary Research in Sustainability Science: Practice, Principles, and Challenges. Sustainability Science, 7, 25-43. https://doi.org/10.1007/s11625-011-0149-x

[37] Jahn, T., Bergmann, M. and Keil, F. (2012) Transdisciplinarity: Between Mainstreaming and Marginalization. Ecological Economics, 79, 1-10. https://doi.org/10.1016/j.ecolecon.2012.04.017

[38] Mauser, W., Klepper, G. and Rice, M., Schmalzbauer, B.S., Hackmann, H., Leemans, R. and Moore, H. (2013) Transdisciplinary Global Change Research: The Co-Creation of Knowledge for Sustainability. Current Opinion in Environmental Sustainability, 5, 420-431. https://doi.org/10.1016/j.cosust.2013.07.001

[39] Brandt, P., Ernst, A., Gralla, F., Luederitz, C., Lang, D.J., Newig, J., Reinert, F., Abson, J.D. and Wehrden, V.H. (2013) A Review of Transdisciplinary Research in Sustainability Science. Ecological Economics, 92, 1-15.

https://doi.org/10.1016/j.ecolecon.2013.04.008

[40] Marshall, J. (2014) Transdisciplinarity and Art Integration: Toward a New Understanding of Art-Based Learning across the Curriculum. Studies in Art Education, 55, 104-127. https://doi.org/10.1080/00393541.2014.11518922

[41] Lin, L., Liu, M., Luo, F., Wang, K., Zhang, Q. and Xiang, W.-N. (2012) Comment on "The Study of Urban Metabolism and Its Applications to Urban Planning and Design” by Kennedy, et al. (2011). Environmental Pollution, 167, 184-185. 
https://doi.org/10.1016/j.envpol.2012.04.011

[42] Knüppe, K. and Pahl-Wostl, C. (2011) A Framework for the Analysis of Governance Structures Applying to Groundwater Resources and the Requirements for the Sustainable Management of Associated Ecosystem Services. Water Resources Management, 25, 3387-3411. https://doi.org/10.1007/s11269-011-9861-7

[43] Mainalia, B., Ngoa, H.H., Guoa, S.W., Phama, N.T.T., Wang, C.X. and Johnstonc, A. (2011) SWOT Analysis to Assist Identification of the Critical Factors for the Successful Implementation of Water Reuse Schemes. Desalination and Water Treatment, 32, 297-306. https://doi.org/10.5004/dwt.2011.2714

[44] Nagara, G., Lam, W.H., Lee, N.C.H., Othman, F. and Shaaban, M.G. (2015) Comparative SWOT Analysis for Water Solutions in Asia and Africa. Water Resources Management, 29, 125-138. https://doi.org/10.1007/s11269-014-0831-8

[45] Nagy, J. and Zseni, A. (2016) Swot Analysis of Dry Toilets. WIT Transactions on Ecology and the Environment, 203, 257-268. https://doi.org/10.2495/EID160231

[46] Gao, X., Chen, L., Sun, B. and Liu, Y. (2017) Employing SWOT Analysis and Normal Cloud Model for Water Resource Sustainable Utilization Assessment and Strategy Development. Sustainability, 9, Article No. 1439.

https://doi.org/10.3390/su9081439

[47] Hill, T. and Westbrook, R. (1997) SWOT Analysis: It's Time for a Product Recall. Long Range Planning, 30, 46-52. https://doi.org/10.1016/S0024-6301(96)00095-7

[48] Cheng, S., Zheng, L., Zhao, M., Bai, X., Li, Z. and Heinz-Peter, M. (2017) Assessment of Two Faecal Sludge Treatment Plants in Urban Areas: Case Study in Beijing. International Journal of Agricultural and Biological Engineering, 10, 237-245.

[49] Mor, S., Kaur, K. and Khaiwal, R. (2016) SWOT Analysis of Waste Management Practices in Chandigarh, India and Prospects for Sustainable Cities. Journal of Environmental Biology, 37, 327-332.

[50] Unal, M., Cilek, A. and Guner, D.E. (2020) Implementation of Fuzzy, Simos and Strengths, Weaknesses, Opportunities and Threats Analysis for Municipal Solid Waste Landfill Site Selection: Adana City Case Study. Waste Management \& Research, 38, 45-64. https://doi.org/10.1177\%2F0734242X19893111

[51] Akhobadze, G.N. (2018) SWOT Analysis of Industrial Wastewater. IOP Conference Series: Materials Science and Engineering, 451, Article ID: 012212.

https://doi.org/10.1088/1757-899X/451/1/012212

[52] Ogu, I.V. (2010) Evolutionary Dynamics of Urban Land Use Planning and Environmental Sustainability in Nigeria. Planning Perspectives, 14, 347-368. https://doi.org/10.1080/026654399364175

[53] African Population and Health Research Center (APHRC) (2016) Solid Waste Management and Risks to Health in Urban Africa: A Study of Dakar City, Senegal. Technical Report, African Population and Health Research Center, Nairobi.

[54] Bouraima, Z. (2017) Sociologie de l'assainissement: Latrinisation, représentations sociales et logiques d'action dans les villes moyennes au Burkina Faso, Ph.D. Thesis, Université Toulouse le Mirail-Toulouse II, France.

[55] Rosemarin, A., McConville, J., Flores, A. and Zhu, Q. (2012). The Challenges of Urban Ecological Sanitation: Lessons from the Erdos Eco-Town Project. Practical Action Publishing, Rugby.

http://www.diva-portal.org/smash/record.jsf?pid=diva2\%3A575781\&dswid=-8358

[56] UN-Water (2015) Wastewater Management-A UN-Water Analytical Brief. https://www.unwater.org/publications/wastewater-management-un-water-analytica 
1-brief/

[57] Serrano-Ruiz, J.C., Luque, R., Campelo, M.J. and Romero, A.A. (2012) Continuous-Flow Processes in Heterogeneously Catalyzed Transformations of Biomass Derivatives into Fuels and Chemicals. Challenges, 3, 114-132.

https://doi.org/10.3390/challe3020114

[58] Arancon, D.A.R., Lin, K.S.C., Chan, M.K., Kwan H.T. and Luque, R. (2013) Advances on Waste Valorisation: New Horizons for a More Sustainable Society. Energy Science and Engineering, 1, 53-71. https://doi.org/10.1002/ese3.9

[59] Vea, B.E., Romeo, D. and Thomsen, M. (2018) Biowaste Valorisation in a Future Circular Bioeconomy. Proceedings of CIRP, 25th CIRP Life Cycle Engineering (LCE) Conference, Vol. 69, Copenhagen, 30 April-2 May 2018, 591-596.

https://doi.org/10.1016/j.procir.2017.11.062

[60] Andersson, K., Rosemarin, A., Lamizana, B., Kvarnström, E., McConville, J., Seidu, R., Dickin, S. and Trimmer, C. (2020) Sanitation, Wastewater Management and Sustainability: From Waste Disposal to Resource Recovery. 2nd Edition, United Nations Environment Programme and Stockholm Environment Institute, Nairobi and Stockholm.

[61] Park, D.N., Thring, W.R., Garton P.R., Rutherford, P.M. and Helle, S.S. (2011) Increased Biogas Production in a Wastewater Treatment Plant by Anaerobic Co-Digestion of Fruit and Vegetable Waste and Sewer Sludge-A Full Scale Study. Water Science \& Technology, 64, 1851-1856. https://doi.org/10.2166/wst.2011.753

[62] Rezania, S., Ponraj, M., Talaiekhozani, A., Mohamad, E.S., Din, Md. F.M., Taib, M.S., Sabbagh, F. and Md Sairan, F. (2015) Perspectives of Phytoremediation Using Water Hyacinth for Removal of Heavy Metals, Organic and Inorganic Pollutants in Wastewater. Journal of Environmental Management, 163, 125-133. https://doi.org/10.1016/j.jenvman.2015.08.018

[63] Oktorina, N.A., Achmad, Z. and Mary, S. (2019) Phytoremediation of Tofu Wastewater Using Eichhornia crassipes. Journal of Physics. Conference Series, 1341, Article ID: 052009. https://doi.org/10.1088/1742-6596/1341/5/052009

[64] Mishra, S. and Maiti, A. (2017) The Efficiency of Eichhornia crassipes in the Removal of Organic and Inorganic Pollutants from Wastewater: A Review. Environmental Science and Pollution Research, 24, 7921-7937. https://doi.org/10.1007/s11356-016-8357-7

[65] Mahamadi, C. (2011) Water Hyacinth as a Biosorbent: A Review. African Journal of Environmental Science and Technology, 5, 1137-1145.

[66] Rezania, S., Ponraj, M., Din, M.F.M., Songip, A.R., Sairan F.M. and Chelliapan S. (2015) The Diverse Applications of Water Hyacinth with Main Focus on Sustainable Energy and Production for New Era: An Overview. Renewable \& Sustainable Energy Reviews, 41, 943-954. https://doi.org/10.1016/j.rser.2014.09.006

[67] Sauer, T., Barnebeck, S., Kalff, Y., Schicklinski, J., Elsen, S., Garzillo, C., Hopp, J. and Kuhn S. (2015) The Role of Cities in the Socio-Ecological Transition of Europe (ROCSET). WWW for Europe Working Paper, No. 93, WWW for Europe, Vienna.

[68] Esrey, A.S., Gough, J., Rapaport, D., Sawyer, R., Simpson-Hébert, M., Vargas, J. and Winblad, U. (1998) Assainissement écologique. AgenceSuédoise Internationale pour le Développement (Sida), Stockholm.

[69] Andersson, M. (2014) Assessing the Cultural Potential of Ecological Sanitation in Improving Waste Management and Food Security in the Taita Hills, Kenya. MSc Thesis, University of Helsinki, Helsinki.

[70] Jewitt, S. (2011) Poo Gurus? Researching the Threats and Opportunities Presented 
by Human Waste. Applied Geography, 31, 761-769.

https://doi.org/10.1016/j.apgeog.2010.08.003

[71] Nawab, B., Nyborg, I.L.P., Esser, K.B. and Jenssen, P.D. (2006) Cultural Preferences in Designing Ecological Sanitation Systems in North West Frontier Province, Pakistan. Journal of Environmental Psychology, 26, 236-246. https://doi.org/10.1016/j.jenvp.2006.07.005

[72] Donadei, M. (2019) The Role of Citizen Participation in the Socio-Ecological Transition of the City. Retos, 9, 55-69. https://doi.org/10.17163/ret.n17.2019.04

[73] Berkes, F. (2017) Environmental Governance for the Anthropocene? Social-Ecological Systems, Resilience, and Collaborative Learning. Sustainability, 9, Article No. 1232. https://doi.org/10.3390/su9071232

[74] Eheliyagoda, D. (2016) SWOT Analysis of Urban Waste Management: A Case Study of Balangoda Suburb. Journal of Global Ecology and Environment, 5, 73-82.

[75] Starkl, M., Amerasinghe, P., Essl, L., Jampani, M., Kumar, D. and Asolekar, R.S. (2016) Rapid Assessment and SWOT Analysis of Non-Technical Aspects of Natural Wastewater Treatment Systems. In: Wintgens, T., Nättorp, A., Elango, L. and Asolekar, S.R., Eds., Natural Water Treatment Systems for Safe and Sustainable Water Supply in the Indian Context. Saph Pani, IWA Publishing, London, Chapter. 17, 283-300. https://doi.org/10.2166/9781780408392

[76] Van de Meene, S., Brown, R. and Farrelly, M. (2011) Towards Understanding Governance for Sustainable Urban Water Management. Global Environmental Change, 21, 1117-1127. https://doi.org/10.1016/j.gloenvcha.2011.04.003

[77] Bell, S. (2015) Renegotiating Urban Water. Progress in Planning, 96, 1-28. https://doi.org/10.1016/j.progress.2013.09.001

[78] Ramakrishnaiah, C. (2014) Urban Water Management: Best Practice Cases. Current Urban Studies, 2, 83-87. https://doi.org/10.4236/cus.2014.22009

[79] Strande, L., Schoebitz, L., Bischoff, F., Ddiba, D., Okello, F., Englund, M., Ward, B.J. and Niwagaba, C. (2018) Methods to Reliably Estimate Faecal Sludge Quantities and Qualities for the Design of Treatment Technologies and Management Solutions. Journal of Environmental Management, 223, 898-907. https://doi.org/10.1016/j.jenvman.2018.06.100

[80] Andersson, M. and Minoia, P. (2016) Ecological Sanitation: A Sustainable Goal with Local Choices. A Case Study from Taita Hills, Kenya, African Geographical Review, 36, 183-199. https://doi.org/10.1080/19376812.2015.1134336

[81] Mariwah, S. and Drangert J.-O. (2011) Community Perceptions of Human Excreta as Fertilizer in Peri-Urban Agriculture in Ghana. Waste Management \& Research, 29, 815-822. https://doi.org/10.1177\%2F0734242X10390073

[82] Dietz, T., Ostrom, E. and Stern, P.C. (2003) The Struggle to Govern the Commons. Science, 302, 1907-1912. https://doi.org/10.1126/science.1091015

[83] Inglehart, R. and Wayne, E.B. (2000) Modernization, Cultural Change, and the Persistence of Traditional Values. American Sociological Review, 65, 19-51. https://doi.org/10.2307/2657288

[84] Minato, W., Curtis, A. and Allan, C. (2010) Social Norms and Natural Resource Management in a Changing Rural Community. Journal of Environmental Policy and Planning, 12, 381-403. https://doi.org/10.1080/1523908X.2010.531084

[85] Moser, S., Williams, S.J. and Boesch, D.F. (2012) Wicked Challenges at Land's End: Managing Coastal Vulnerability under Climate Change. Annual Review of Environment and Resources, 37, 51-78. 
https://doi.org/10.1146/annurev-environ-021611-135158

[86] Llamas, R. (2004) Water and Ethics: Use of Groundwater. United Nations Educational, Scientific and Cultural Organization, Paris.

[87] McAdams, M. (2007) Global Cities as Centers of Cultural Influence: A Focus on Istanbul, Turkey. Transtext(e)s Transcultures 跨文本跨文化: Journal of Global Cultural Cities, 3, 151-165. https://doi.org/10.4000/transtexts.149

[88] Garduño, H., van Steenbergen, F. and Foster, S. (2010) Stakeholder Participation in Groundwater Management Enabling and Nurturing Engagement. Briefing Note Series Note 6, GW·MATE, World Bank, Washington DC.

[89] Jabeen, A., Huang, X.S. and Aamir, M. (2015) The Challenges of Water Pollution, Threat to Public Health, Flaws of Water Laws and Policies in Pakistan. Journal of Water Resource and Protection, 7, 1516-1526.

https://doi.org/10.4236/jwarp.2015.717125

[90] Ezenwaji, E., Anyaeze, E. and Nwafor, A. (2018) Improving Self-Supply of Urban Water and Sanitation Projects through Microfinancing in Nigeria. Journal of Geoscience and Environment Protection, 6, 20-33.

https://doi.org/10.4236/gep.2018.62002

[91] Ezenwaji, E.E. and Eduputa, B.M. (2016) Self Supply as a Traditional Model for the Improvement of Water Supply in Onitsha, Nigeria. Proceedings of the 39 th WEDC International Conferences, Kumasi, 11-15 July 2016, 81-94.

[92] Lupala, J. (2014) The Social Dimension of Sustainable Development: Social Inclusion in Tanzania's Urban Centres. Current Urban Studies, 2, 350-360.

https://doi.org/10.4236/cus.2014.24033 